\title{
Improving cost performance in design-bid-build road projects by mapping the reasons for cost overruns into the project phases
}

María Calahorra-Jimenez (Main and Corresponding autor)

Department of Construction Engineering and Management, School of Engineering, Pontificia Universidad Católica de Chile

Ave. Vicuña Mackenna 4860, Santiago (Chile)

Department of Civil, Environmental, and Architectural Engineering, College of Engineering \& Applied Science, University of Colorado Boulder

1111 Engineering Dr. 428 UCB, Boulder, CO 80309-0428 (USA)

micalahorra@uc.cl and maria.calahorra@colorado.edu

\section{Luis Fernando Alarcón}

Department of Construction Engineering and Management, School of Engineering, Pontificia Universidad Católica de Chile

Ave. Vicuña Mackenna 4860, Santiago (Chile)

lalarcon@ing.puc.cl

\section{Cristina Torres-Machi}

Department of Civil, Environmental, and Architectural Engineering, College of Engineering \& Applied Science, University of Colorado Boulder

1111 Engineering Dr. 428 UCB, Boulder, CO 80309-0428 (USA)

Cristina.TorresMachi@colorado.edu

\section{Alondra Chamorro}

Department of Construction Engineering and Management, School of Engineering, Pontificia Universidad Católica de Chile

Ave. Vicuña Mackenna 4860, Santiago (Chile)

achamorro@ing.puc.cl

\section{Keith Molenaar}

Department of Civil, Environmental, and Architectural Engineering, College of Engineering \& Applied Science, University of Colorado Boulder

1111 Engineering Dr. 428 UCB, Boulder, CO 80309-0428 (USA)

keith.molenaar@colorado.edu

Manuscript Code: 14076

Date of Acceptance/Reception: 01.06.2020/04.11.2019

DOI: 10.7764/RDLC.19.2.334

\section{Abstract}

Design-Build (DB) is an alternative project delivery system that has shown to be better in controlling cost growth than the traditional Design-Bid-Build (DBB) system. However, some road administrations are not legally allowed to implement DB and keep using DBB with consequent disadvantages, such as having high-cost overruns. There is a need, therefore, to provide road administrators delivering DBB projects with research-based mitigation measures that can help them to minimize the main reason for cost overruns. To this end, this study identifies the main reasons for cost overruns in the design, the procurement and the construction phases of DBB road projects and point out to the specific elements of DB project delivery that might help to minimize these reasons. To identify the reasons, an exploratory content analysis was performed on interviews conducted with 41 professionals involved in road project management in Chile. Literature review and document analysis of DB were used to analyze the identified reasons under the framework of the DB practice in the United States. The results showed that four elements based on the DB approach might be used to minimize cost overruns in DBB projects: (1) in the design phase, road administrators should consider the early integration of the constructor's expertise. In the procurement phase, they should establish (2) instances for effective information exchange and (3) a goal-oriented selection process. Overall, road administrators should consider (4) establishing a one-point of high-level accountability for the design, the procurement, and the construction phases. This study will serve DBB road administrators to start the transition from DBB to more collaborative approaches that will help to minimizer cost overruns and, therefore, to improve the project cost performance.

Keywords: Cost overruns, Road projects, Design-bid-build, Design-build, Content analysis. 
One of the major challenges facing public administrators over the last 50 years has being how to meet cost goals in public infrastructure projects (Flyvbjerg, Holm, \& Buhl, 2002).

Public administrators use contracting strategies to develop road projects. Through these strategies, they undertake all processes to obtain a complete project design and thereby complete the construction (Touran et al., 2008). Generally, the contracting strategy comprises three elements: project delivery systems, procurement methods, and contract approaches (Molenaar, Harper, \& Yugar-Arias, 2014).

In this research, the project delivery system is defined as the model for the processes of designing and constructing infrastructures(Forbes \& Ahmed, 2011). Traditionally, public administrators have adopted the Design-Bid-Build (DBB) system, which involves contracting the design and the construction independently. The advantages associated with this method are its long history of acceptance and its ability to provide open competition, to establish a clear distinction between roles, to permit flexibility for the owner and to facilitate the process of bidding (Pakkala, 2002). However, the separation of the designer and the constructor activities generates some disadvantages, such as the lack of innovation, the linearity of the process, the lack of timely and qualified input from the contractor, and the higher odds of overruns and disputes between parties (AIA, 2007; Brierley, Corkum, \& Hatem, 2010; Hasanzadeh, Esmaeili, Nasrollahi, Gad, \& Gransberg, 2018; Pakkala, 2002). Moreover, in this project delivery system, public administrators assume most of the risks and are responsible for the errors and omissions of the design (Pakkala, 2002).

Some of the flaws inherent in DBB system have been addressed using other methods, such as Design-Build (DB) (AIA, 2007; Forbes \& Ahmed, 2011). This approach implies that the public administrator procures both the design and construction from a single firm (Miller, 2000). This method allows more flexibility in developing the design and in procuring the construction of the project (Cheung, Yiu, \& Lam, 2013; Sullivan, El Asmar, Chalhoub, \& Obeid, 2017). It also promotes and enhances communication between the teams, which is crucial to improve project performance (Tran, Nguyen, \& Faught, 2017; US Federal Government, 2002). Further, in DB, public administrators generally use best-value procurement to select the teams that will develop the work (AASHTO, 2018). In best-value (unlike low bid procurement), decision-makers use several criteria in addition to price to award the contract (Scott, Molenaar, Gransberg, \& Smith, 2006). Considering not only price in the selection makes it more likely to select the best contractor possible (Akcay \& Manisali, 2018; Yu \& Wang, 2012). Choosing the best contractor possible, therefore, can reduce risks in project development (Morledge \& Smith, 2013). All these reasons have led DB to become a viable option for the construction of road projects despite the cultural and legislative barriers that it has faced in its implementation (De Witt et al., 2005; FMI, 2018; Sullivan et al., 2017). Still, some countries face legal difficulties in DB implementation in road projects (Alarcón, Wegmann, \& Calahorra, 2018; Lam, Chan, Albert, \& Chan, 2006).

Numerous studies have compared the effectiveness of DB and DBB systems (FHWA, 2006, 2017; Minchin Jr., Li, Issa, \& Vargas, 2013; Park \& Kwak, 2016; Shrestha, Migliaccio, O’Connor, \& Gibson, 2007; Tran, Diraviam, \& Minchin Jr, 2018). For instance, Sullivan et al. (2017) is a representative example. These authors analyzed 30 studies-published in the last 20 years - that represent 4,623 projects. These studies contained projects' information about the delivery approach and the cost outcomes. The analysis allowed researchers to compare the cost performance between project delivery methods. The results showed that the DB delivery method is more effective in controlling the cost growth $(+2.8 \%)$ than DBB (+5.1\%). However, these studies did not examine the possible reasons that lead DB to experience fewer cost overruns than DBB.

Previous research has addressed the reasons for cost overruns in construction projects worldwide including the United States (Bordat, McCullouch, Labi, \& Sinha, 2004; Shane, Molenaar, Anderson, \& Schexnayder, 2009), Australia (Creedy et al. 2010), Asia (PMI, 2014; Rosenfeld, 2014; World Bank, 2014), South Africa (Khabisi, Aigbavboa, \& Thwala, 2016), Europe (Stefan Verweij, van Meerkerk, \& Korthagen, 2015) and South America (Tala González, 2015). Most of these research found reasons for cost overruns associated with three broad areas: design, project changes, and procurement.

Design. Shane et al. (2009) identified as one of the main reasons for cost overruns "poor estimating," which, according to these authors, led to "errors and omissions from plans and quantities as well as general inadequacies and poor performance in planning and estimating procedures and techniques." Creedy et al. (2010) analyzed data collected from 231 highway projects in Queensland and found as relevant factors leading to cost overruns: insufficient investigations, deficient specifications and design, and lack of constructability. Another evidence supporting errors and omission in design as a reason for cost overruns is the results of a pilot study developed by the World Bank based on roadworks. It suggested that some of the common reasons for delays and cost overruns were poor preliminary studies, inadequate site investigations and incomplete, delayed or inaccurate designs (with error and omissions) (World Bank, 2014). Within 
the public sector, Khabisi et al. (2016) identified as cost overrun factors: errors and omissions in design, inaccurate estimation of time and cost, and inexact quantities. Another evidence emphasizing design aspects as reasons for cost overruns and delays is Tala (2015). His thesis explores construction projects developed by the Ministry of Public Works in Chile, and one of his findings was that almost $70 \%$ of the main reasons for construction cost overruns and delays are influenced by problems in previous phases of the project lifecycle (pre-design and design).

Project changes. According to Love et al. (2012), rework during construction as a result of design changes and errors and omission is a significant contributor to overruns in projects. Several authors agree to consider changes as a fundamental reason for cost overruns. Shane et al. (2009) identified as a reason for cost escalation changes in schedule and scope. They considered that changes in schedule could be due to, for example, design changes or budget constraints. Scope changes may include alteration in design and dimensions as well as increases in project elements. Creedy et al. (2010) found that the first principal factor of cost overrun was design and scope change. For highway projects, the Indian Project Management Institute found that two of the main factors having a higher impact on project cost were the scope creep and the design change (PMI, 2014). Rosenfeld (2014) developed a cross-sectional survey for ranking the 15 root causes of construction cost overruns. The second one was "too many changes in owners' requirements or definitions." Khabisi et al. (2016) identified as cost overrun factors within the public sector: change orders, change in scope, and design changes. Verweij and Meerkerk (2015) analyzed a total of 2,804 contract changes in the 45 projects (with $84,4 \%$ of the projects being roads). They found that scope changes were the most significant reason for cost overruns in transportation infrastructure projects.

Procurement. Several researchers also identified aspects related to procurement. Bordat et al. (2004) found that influential factors of cost overrun of Indiana Department of Transportation (DOT) highway contracts included: the contract bid amount, difference between the winning bid and second bid, and the difference between the winning bid and the engineer's estimate. Shane et al. (2009) mentioned the delivery and procurement approach as a reason for cost overruns. Rosenfeld (2014) found as the most critical reason for cost overruns having premature tender documents (drawings, bill of quantities, specifications, contracts, and legal documents); Khabisi et al. (2016) identified as one of the cost overruns factor within the public sector the policy of accepting the lowest tender in the procurement.

Generally, all these studies resulted in lists and ranking of reasons, some of them suggesting generic recommendations to mitigate those reasons. These studies, however, did not provide a structured analysis that served as a basis to propose those recommendations.

The purpose of this research is to propose a structured approach to provide measures based on DB practices that can help DBB road projects to mitigate the principal reasons that lead to cost overruns. The study contributes to exploring the reasons for cost overruns and their link with some aspects of the project delivery system by identifying and mapping them in the phases of design, procurement, and construction of DBB road projects. This mapping constitutes the point of departure to find specific elements of DB project delivery that might help to minimize these reasons.

An overview of relevant literature has been first introduced. Then, the methodology section describes the data collection and methods used to analyze the data. Finally, the result, the discussion, and conclusion sections are developed.

\section{Methodology}

To find the main reasons for cost overruns into the three phases of a road project-that is design, procurement, and construction - an exploratory content analysis was performed based on the interviews conducted with 41 professionals involved in road project management in Chile. This study conducted literature review and analysis of DB procurement documents-including DB Manuals and Request For Proposals (RFPs) - to analyze the identified reasons under the framework of the DB practice in the United States.

This research focuses on the DB because public administrators have successfully implemented it on delivering road projects. In several cases, DB saved construction costs, improved quality, and provided benefits associated with innovative solutions (DBIA, 2014).

\section{Content Analysis}

According to Krippendorff (1980), content analysis is a research method that allows obtaining replicable and valid inferences from data within the context from which they were taken. The method aims to provide knowledge, new insight, facts illustration, and constructive drivers to action. Fellows \& Liu (2015) considered this technique within the 
domain of construction management. They mention that inductive content analysis may be used to determine the most important aspects of a data set by counting the number of times that a topic is mentioned in that set. Several authors have used content analysis to address construction issues, such as DB evaluation criteria (Xia, Chan, Zuo, \& Molenaar, 2011; Xia, Skitmore, \& Zuo, 2011), construction contracts (Stanford, Molenaar, \& Sheeran, 2016) or performance measures (Harper, Molenaar, Anderson, \& Schexnayder, 2014).

This study uses the steps for developing inductive content analysis introduced by Elo \& Kyngas (2008). Moving through the phases of open coding, creating categories and abstraction, the study was able to determine what these professionals believed to be the primary causes of cost overruns taking place in each of the design, the procurement and the construction phases of road projects.

\section{Data collection}

This study was part of a major research project awarded in 2017 by the Public Policy Center of the Catholic University of Chile. The Public Policy Center aims to encourage cross-functional work between scholars regarding public issues of general concern. Chilean Director of Public Works, Former Secretary of Public Works, President of the Public Infrastructure Committee of the Chilean Chamber of Construction, as well as professionals from the Department of Public Works and Roads, were involved in the research project and the presentations and seminars conducted in its framework. They followed the progression of the project and provided feedback and validation to the research team.

As part of the project, multiple semi-structured interviews, including three open-ended questions, were conducted with 41 professionals involved in the management of public interurban road projects in Chile. These professionals were selected from public administrations (51\%) and private companies (49\%), based on their level of experience and involvement in the phases of the design, procurement, and construction of road projects in Chile. The average experience of the professionals was 17 years. They were asked the following questions: Question 1 (Q1), Could you identify, at least, three main reasons associated with the design phase that highly impact construction cost overruns? Question 2 (Q2), Could you identify, at least, three main reasons related to the procurement phase that profoundly impact construction cost overruns? Question 3 (Q3), Could you identify at least three main reasons related to the construction phase that highly influence construction cost overruns? The aim of asking these questions was to identify the main reasons affecting cost overruns that could be associated (as events) with each of the phases. The interviewees provided their written responses electronically.

\section{Data analysis}

The written answers were recorded in the software dedoose (https://www.dedoose.com/), where one document was created for each answer.

In the first step of content analysis, open coding, the researcher followed a traditional approach adopted in social sciences, allowing the codes to emerge from the data (Creswell, 2009). In this research, the codes emerged from the recorded interviews' answers. Each code represented a reason leading to cost overruns. The analysis identified 118 codes. The responses were re-read, aiming to create higher-level codes that gather similar concepts. Afterward, the researches established 78 final codes and listed them with their definition in the research's codebook. Using the research's codebook, researchers assigned the final codes using two independent coders.

According to Neuendorf (2002), reliability "is the extent to which a measuring procedure yields the same results on repeated trials. The notion relevant to content analysis is that a measure is not valuable if it can be conducted only once or only by one particular person." The author states that, in content analysis, when humans assign the codes, the reliability translates in intercoder reliability. The intercoder reliability in this research was measured using Cohen's kappa coefficient. Cohen's Kappa coefficient (k) is a statistical measure of the level of agreement between two independent raters that takes into account that the possibility of agreement could occur by chance alone (Salabeddin M., 2012). Precisely, $k$ is calculated using the following equation:

$$
k=P o-\frac{P e}{1-P e}
$$

Where,

Po: is the proportion of the observed agreement between the two raters

$\mathrm{Pe}$ : is the proportion of rater agreement expected by chance alone. 
$\mathrm{K}$ equal to +1 implies complete agreement, and $\mathrm{k}$ equal to 0 indicates a lack of agreement between the raters (Salabeddin M., 2012). The intercoder reliability in this research obtained a Cohen's kappa of 0.72, which corresponds to a good agreement (Domenic, 1994; Fleiss, 1972; Landis \& Koch, 2013).

The second step of the content analysis included the creation of categories to describe the phenomenon, increase its understanding, and generate knowledge (Krippendorff, 1980). Affinity diagrams were used to organize and establish groups of codes (Carnevalli \& Miguel, 2008). The affinity diagrams sort data and find underlying relationships linking the resulting groups (Andersen \& Fagerhaug, 2006).

Each code represented a reason for cost overrun. Researchers ordered the codes by the percentage of agreement between the interviewees. The percentage of agreement was calculated by dividing the number of each code appearance -in each question - by the number of interviewees. Only the reasons with more than $10 \%$ of the agreement were considered for the analysis. Questions Q1, Q2, and Q3 focused on each of the design, procurement, and construction phases. However, some of the interviewees' answers referred to reasons for cost overruns associated with other phases not mentioned in the question.

For this reason, the researchers analyzed the group of codes associated with the questions Q1, Q2, and Q3. In each group, researchers filtered each reason by asking where it usually occurred (i.e., whether the reason happened in the design, the procurement, or, in the construction phase). The filtering process resulted in re-assigning codes to different phases from the one that generated the code. For example, question Q1, which referred to reasons in the design phases, had as a codified reason "utility relocation issues." This reason does not occur in the design phase; thus, it was reassigned to the construction phase. Finally, each code-representing a reason-was associated with the phase in which that code (as an event) occurred.

Finally, the third step of the content analysis was abstraction. This meant to formulate a general description of the research topic through the categories that had been generated in prior steps of content analysis (Robson, 1993). This research builds a discussion upon how the reasons identified in each of the design, procurement, and construction phases can be mitigated by implementing elements from the DB project delivery approach.

From each of the phases, the researchers obtained three groups of codes representing the main important reasons for cost overruns identified by the interviewees.

When asking for the reasons for cost overruns associated with the design phase (Q1), "Errors \& Omissions in the design" was the cause with the highest percentage of agreement-with approximately $40 \%$ of consensus among the interviewees. "Inadequate designer capabilities" stood out with roughly $35 \%$ of the agreement. The interviewees highlighted specific features associated with the lack of capability, such as "lack of designers' experience" and "lack of designers' local knowledge." Lastly, "Lack of proper basic engineering," achieved 27\% of agreement among the participants, this reason includes "poor topography", "poor soils identification and/or geotechnical studies", and "poor general baseline of the area affected by the project."

When asking for the reasons for cost overruns associated with the procurement phase (Q2), the most frequently mentioned cause identified among participants was "vague, incoherent, and with errors Request for Proposal (RFP)" with around $23 \%$ of agreement. "Short time to study and clarify the RFP" achieved $13 \%$ while "lack of proper information exchange" reached $10 \%$ of agreement.

When asking for the reasons for cost overruns associated with the construction phase (Q3), "inadequate constructor capabilities \& interest" stood out with roughly $30 \%$. The following main reasons, with $13 \%$ of agreement" was related to "project changes". The interviewees specified some of the reasons leading to "project changes", such as "project outdated", "in situ adjustments to real conditions", "change of soil foundation conditions", and "need to include new items during construction". Finally, "long time between design and construction" was mentioned with a $10 \%$ agreement among the interviewees.

Figure 1 maps the main reasons identified through the phases of the design, procurement, and construction. 
Figure 1. Reasons for cost overruns in design-bid-build road projects. Source: Self-elaboration.

DESIGN

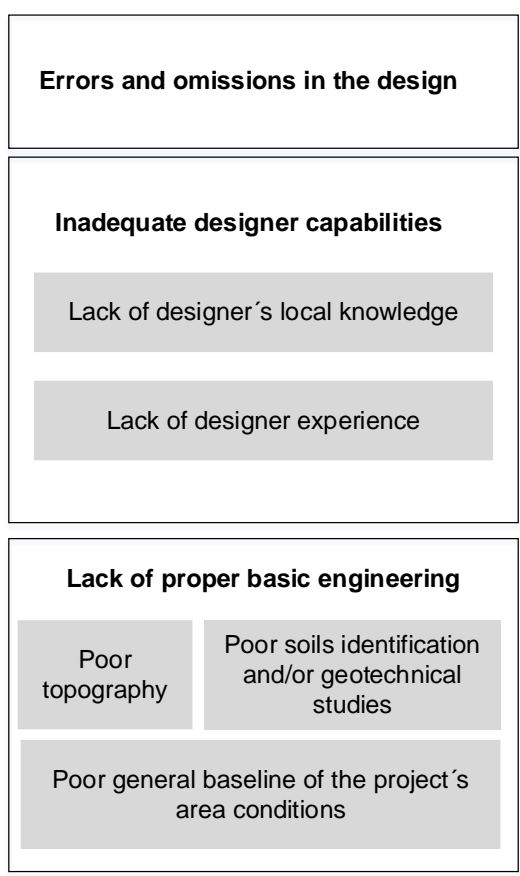

PROCUREMENT

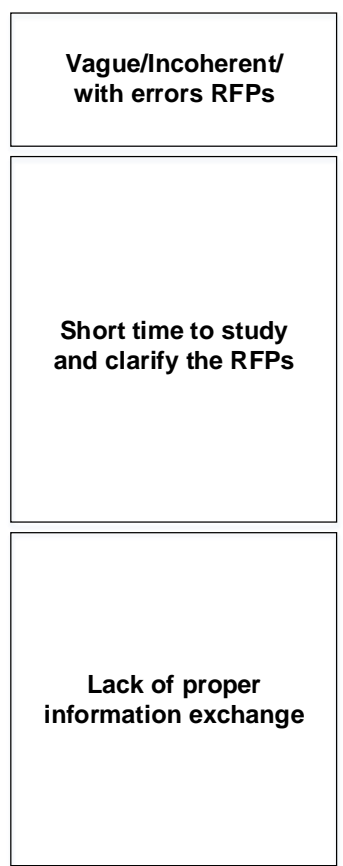

CONSTRUCTION

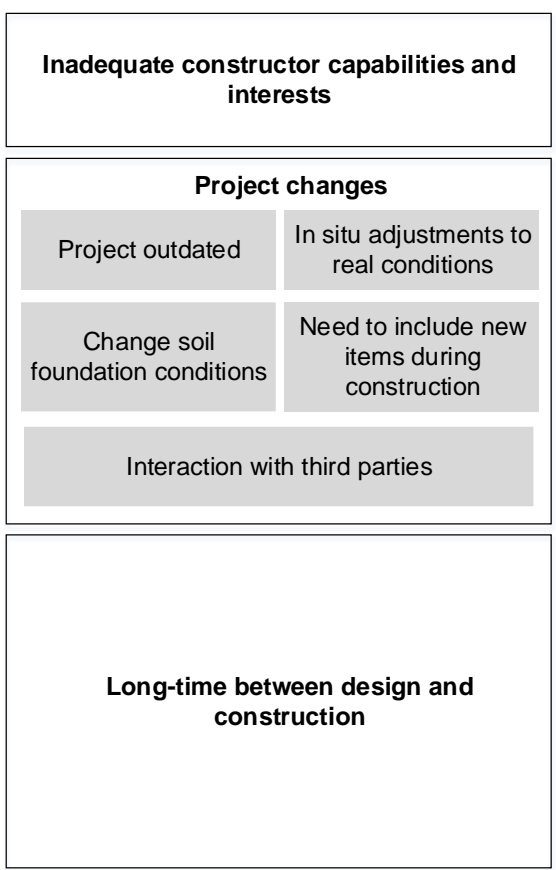

To discuss how elements associated with DB can be considered to minimize cost overruns in road projects delivered using DBB, the researchers mapped the main reasons for cost overruns in DBB road projects into the design, the procurement, and the construction phases. The reasons for cost overruns obtained in each phase were analyzed under the DB approach to finding elements that could be implemented in that phase of the DBB process to minimize these reasons for cost overruns.

\section{Design related reasons}

Which DB's practices can be considered in the design phase of DBB road projects to minimize the main reasons for cost overruns associated with this phase? The research identified three main reasons for cost overruns related to the design phase: "errors and omissions in the design," "inadequate designer capabilities", and "lack of proper basic engineering principles". These reasons align with finding from previous research that focused on the reasons for cost overruns in the design (Creedy et al., 2010b; Khabisi et al., 2016; Shane et al., 2009; Tala González, 2015; World Bank, 2014). In the following paragraphs, the authors discuss the design-related reasons under the lens of DB practice.

Errors and omissions in the design. AIA (2007) acknowledges that part of the inefficiencies associated with DBB are related to the separations of responsibilities that lead the design team and the construction team to have different objectives and interests. "Errors or omissions in the design" might be reduced by involving the design and the construction parties in the early stages of the project. Highways England is an example of a road administrator that recognizing relevant problems associated with DBB-including cost overruns around 35\%-decided to transition to alternative project delivery methods. They established a long-term plan to introduce changes in the management and delivery of transportation projects. Further, they introduced a variety of strategies, including design-build contracts and early contractor involvement (De Witt et al., 2005).

Inadequate designer capabilities. The decision-making needed to select the ideal contractor possible-to achieve the project objectives in the design - requires including additional evaluation criteria besides the price (Akcay \& Manisali, 2018). The reasons for having "inadequate designer capabilities" might be minimized by using a selection process that enables road administrators to align the selection of the firms with the project goals. Best-value procurement is a method-currently used in DB road projects - that have the potential of achieving this alignment. In the procurement related section, the details for the application of this method will be addressed. 
Lack of proper basic engineeringand specificallythe "lack of appropriate subsurface investigations", entails two shortcomings in DBB projects. First, the lack of ability to obtain timely and qualified contractor's input during the design. These inputs could be related to constructability and scope definition. Second, the designer's lack of knowledge of construction means and methods with the consequent inability to anticipate how contractor choices will influence the behavior of site conditions (Brierley et al., 2010). The DB project delivery with the integration of designer and constructor can provide an excellent context to achieve a fairer contractual understanding in risk allocation for subsurface conditions (Brierley et al., 2010).

In summary, the early integration of the constructor's expertise is the answer to the question stated at the beginning of this section. Road administrators procuring DBB road projects should consider including the constructor's expertise in the design phase. The contractor's early involvement might help them 1) to reduce errors and omissions in the design as well as (2) to adequately allocate risks associated with gathering adequate information related to basic engineering.

\section{Procurement related reasons}

Which DB's practices can be considered in the procurement phase of DBB road projects to minimize the main reasons for cost overruns associated with this phase? The research identified three main reasons for cost overruns related to the procurement phase: "vague, incoherent and with errors Request for Proposal (RFP)," short time to study and clarify the RFP", and "lack of proper information exchange". Some of these reasons align with findings from previous research that focused on the reasons for cost overruns in procurement (Bordat et al., 2004; Khabisi et al., 2016; Rosenfeld, 2014; Shane et al., 2009). In the following paragraphs, the authors discuss the procurement related reasons under the lens of DB practice.

Vague incoherent and with errors RFP. In the RFPs, road administrators establish the technical and legal requirements that the firms developing the work must accomplish. This document lays the foundations for work performance once the contract is awarded. Thus, clarity and lack of ambiguity are desired to minimize problems in construction. According to Tran et al. (2017), communication between the road administrator and the proposers during the procurement is critical to the success of the projects. In DB procurement in the United States, early exchange of information between the road administrators and the proposers is encouraged. One example of this early exchange of information is the issuance of a draft of RFP for industry review (U.S. Federal Government, 2002). There review process results in the final RFP, in which ambiguities and doubts should have been resolved between the parties involved.

Short time to study and clarify the RFP and lack of proper information exchange. Regarding the former, interviewees explained that the time available once all the information needed is release, is not enough to prepare the proposal. Thus, they set forth that the information exchange process in the procurement is not efficient. In the procurement of DB road projects in the United States, several instances for information exchange between road administrators and proposers are established. One example is informational meetings to introduce general information to the proposers. Another example is the one-on-one meetings to clarify any ambiguous information of the RFP draft. Also, the open forum meetings or mandatory pre-bid meetings to summarize and highlight the most relevant aspects of the RFP and written request for clarifications to make clear any ambiguous aspect of the RFP.

DBB road administrators should tailor - for the procurement process-information exchange activities that fit in their regulatory framework. These activities should aim to facilitate clear and unambiguous information to the proposers so they can prepare proposals adjusted to the road administrator requirements.

In addition to the reasons found in the procurement phase, both in the design and in the construction phases, interviewees identified the "lack of adequate designer and constructor capabilities" as leading causes to cost overruns. A first step towards improving the quality of design and construction teams is to strengthen the selection process that road administrators use to select those teams. As mentioned before, best-value procurement might be an alternative to align the selection process with the project goals. The best-value evaluation takes into account parameters such as time, quality, innovation, and team's qualification and performance. Aspects that require, in turn, the evaluation of the past performance of the team members and the company, the assessment of key personnel's qualifications, and the analysis of evidence related to companies' quality assurance and quality control program (Scott et al., 2006). Assessing, quantifying, and comparing this information enable road administrators to perform a comprehensive evaluation of all the proposers. Therefore, the team that provides better capabilities to the project will stand up among the others, and its selection will contribute to accomplish project goals. According to Morledge and Smith (2013),"selecting the right project team is likely to be the single activity that can reduce most client-road administrator-risks". They indicate that the best team will promote collaboration in the client's interest to guarantee the delivery of the project on-time 
and on-schedule (Morledge \& Smith, 2013). Thus, it will be worthy for DBB road administrators to analyze if their current procurement method enables them to select the best team possible to develop the work.

In summary, establishing instances for effective information exchange in the procurement and well as considering goalbased selection methods - in contrast to cost-driven selection methods-is the answer to the question stated at the beginning of this section. Road administrators procuring DBB road projects should consider defining instances for effective information exchange between the road administrator and the proposers. These instances will help to enhance the understanding of the project scope. A better understanding of the RFP will reduce ambiguities and doubts that otherwise would be translated to project changes and cost overruns in the construction phase.

Also, road administrators procuring DBB road projects should consider the use of best-value procurement for selecting the design team and the construction team since this method has the potential of aligning the selection process with project objectives. This alignment would support the selection of the best team to accomplish the road administrator objectives for the designand the construction phases.

\section{Construction related reasons}

Which DB practices can be considered in the construction phase of DBB road projects to minimize the main reasons for cost overruns associated with this phase? The research identified three main reasons for cost overruns related to the construction phase: "inadequate constructor capabilities and interests," "project changes", and "long time between design and construction". Previous research found "inadequate constructor capabilities" as well as "long time between design and construction" reasons associated with the traditional contracting strategy (i.e., DBB and low bid procurement) (Park \& Kwak, 2016; Yu \& Wang, 2012). Project changes have been profusely identified in previous research on the reasons leading to cost overruns (Creedy et al., 2010; Khabisi et al., 2016; Love et al., 2012; PMI, 2014; Rosenfeld, 2014; Shane et al., 2009; Verweij \& Meerkerk, 2015). In the following paragraphs, the authors discuss the construction-related reasons under the lens of DB practice.

Inadequate constructor capabilities. Similarly to the designer selection, the decision-making needed to select the best team possible-to achieve the project objectives in construction-requires to include additional evaluation criteria besides the price (Akcay \& Manisali, 2018).

The reasons for having "inadequate constructor capabilities and interests" might be minimized by using a selection process that enables road administrators to align the selection with the project goals. Best-value procurement is a method-currently used in DB road projects - that have the potential of achieving this alignment. In the procurement related section, the details for the application of this method have been addressed.

Project changes. Different reasons lead to project changes in construction. Interviewees in this research mentioned causes such as "project updated", "in situ adjustments to real conditions", "changes in soil foundation conditions ,"need to include new items during construction", or "interaction with third parties". FHWA (2017) highlighted that changes due to quantity modifications and errors and omissions were higher in DBB projects (+3\% cost growth) as compared with similar DB projects ( $+0.7 \%$ cost growth). One of the reasons for the difference in number and magnitude of change orders between these project delivery systems can be the early involvement of design-builders (Hasanzadeh, Esmaeili, Nasrollahi, Gad, \& Gransberg, 2018). Besides, Hasanzadeh et al. (2018) also suggest that the use of best-value procurement would increase the odds of having lower claim costs and higher overall success.

Therefore, incorporating the constructor's expertise in the design phase as well as the using the best-value procurement to select the constructor firm might be two measures to include in DBB projects to minimize change orders in the construction phase.

A long time between design and construction would be eliminated by using DB method since the designer, and the constructor are hired together (Miller 2000). In DBB, road administrators might consider this aspect by looking for options to create high-level accountability for the design and the construction phases together. This accountability would track and control the duration of the phases as well as the time between them. Further, it would warranty the necessary funding to keep a smoothie progression between the stages of the project.

In summary, early integration of constructor's expertise and establishing high-level accountability of the design, procurement, and construction phases of a project are the answer to the question stated at the beginning of this section. Road administrators procuring DBB road projects should consider including the constructor's expertise in the design phases. Early contractor's involvement might help them to reduce change orders due to design errors, omissions, 
quantity variation, and lack of constructability. Further, they should establish high-level accountability that considers (1) controlling the duration of the period between the design and the construction and (2) warranting the funding needed for developing the design and the construction. Both accountability elements will help road administrators to keep a smoothie progression of the project phases that will attenuate the segregation among these phases.

Road projects have a challenge in addressing the causes of cost overruns. The purpose of this research was to help DBB road projects to minimize the main reasons for cost overruns in the design, the procurement, and the construction phases; and, therefore, improve the cost performance of this type of projects.

In the design, the main reasons found were "errors and omissions in the design", "inadequate designer capabilities", and "lack of proper basic engineering". In the procurement, these were "vague, incoherent and with errors Request for Proposal (RFP)", "short time to study and clarify the RFP", and "lack of proper information exchange". In the construction, the main reasons found were "inadequate constructor capabilities and interests", "project changes", and "long time between design and construction".

The analysis of these reasons under the collaborative approach of DB suggested four measures that road administrators might implement to minimize the reasons for cost overruns.

1. - In the design phase, early integration of the constructor's expertise. This integration might help (i) to reduce errors and omissions in the design, (ii) to adequately allocate risks associated with gathering adequate information related to basic engineering, and (iii) to minimize change orders due to design errors, omissions, quantity variation, and lack of constructability.

2. - In the procurement phase, there is a need for effective information exchange between the road administrator and the proposers. These instances might help to enhance the understanding of the project scope. At this stage, a better understanding of the RFP will reduce ambiguities and doubts that otherwise would be translated to project changes and cost overruns in the construction phase. As Cheung et al. (2013) stated: "the improvement of information flow would likely improve project performance".

3. - In the procurement phase, there is a need to use a best-value approach to select the design team and the construction team. This procurement method considers different evaluation criteria besides price and thereby enables road administrators to align the selection process with the project objectives. This alignment drives the selection of the best team, which will promote collaboration in the client's interest to guarantee the delivery of the project on-time and on-schedule (Morledge \& Smith, 2013).

4. - In general, establishing one point of high-level accountability for the design, procurement, and construction phases of a project might help these phases to keep a smoothie progression that, in turn, would attenuate the segregation among these phases. This high-level accountability would comprise (1) controlling the duration of the period between the design and the construction and (2) warranting the funding needed for developing the design and the construction.

This research contributes to the knowledge of construction management by building upon previous research on the reasons for cost overruns and mapping these reasons into the project phases. Previous research derived lists of reasons for cost overruns and generic mitigation measures (Bordat et al., 2004; Creedy et al., 2010; Khabisi et al., 2016; KPMG, 2014; Kumaraswamy, 2014; Rosenfeld, 2014; Shane, Molenaar, Anderson, \& Schexnayder, 2009; Tala González, 2015; Stefan Verweij et al., 2015). However, much of this work did not provide a structured analysis as a basis to formulate those measures. This research identified the main reasons for cost overruns in road projects. It used the mapping of these reasons into the phases to provide a framework to discuss mitigation measures through the lens of DB practice.

This study will serve road administrators to start the transition from DBB project delivery to more collaborative approaches that will help minimize the reasons for cost overruns as well as other DBB challenges related to quality issues, inspections' reinforcement, guarantees, and responsibilities. Reducing these aspects, will, in turn, improve the overall project performance.

The main limitation of this research relates to the procedure to collect a portion of the data for this study. The authors used semi-structured interviews. This procedure inhibited researchers' ability to conduct a more throughout validation of the results. This limitation had a slight impact because the authors validated the results by triangulating the findings with the ones obtained from international research. However, future research should be further developed in the identification of cost overruns using case studies that deepen into technical aspects evaluation as well as enable a follow up of the projects analyzed. 
Also, this study suggests future research to explore and compare the links existing between the reasons for cost overruns and the elements comprising different alternative project delivery systems.

\section{Acknowledgments}

The writers wish to acknowledge the support and funding provided by the Centro de Políticas Públicas de la Pontificia Universidad Católica de Chile through the XII award "Propuestas para Chile 2017". Likewise, the authors would like to express their appreciation to Laura Montalban for supporting the cross-checking of the content analysis. Finally, Maria Calahorra would like to thank the economic support given by the Vice-Rector's Office of Research (VRI) of the Pontificia Universidad Católica de Chile, the School of Engineering of the Pontificia Universidad Católica de Chile and the University of Colorado Boulder.

References

AASHTO. (2018). AASHTO Guide for Design-Build Procurement. Washington D.C.: AASHTO.

AIA. (2007). Integrated Project Delivery : A Guide. The American Intitute of Architects (Vol. 1). https://doi.org/10.1016/j.autcon.2010.09.002

Akcay, C., \& Manisali, E. (2018). Fuzzy decision support model for the selection of contractor in construction works. Revista de La Construccion, 17(2), 258-266. https://doi.org/10.7764/RDLC.17.2.258

Alarcón, L. F., Wegmann, A., \& Calahorra, M. (2018). Oportunidades para el mejoramiento de la gestión de proyectos de infraestructura pública en Chile. In Propuestas para Chile, 2017 (pp. 199-239).

Andersen, B., \& Fagerhaug, T. (2006). Root Cause Analysis: Simplified Tools and Techniques (2nd ed.). ASQ Quality press. Retrieved from https://ebookcentral.proquest.com/lib/ucb/detail.action?doclD=1884171.

Bordat, C., McCullouch, B. G., Labi, S., \& Sinha, K. (2004). An analysis of cost overruns and time delays of INDOT projects. FHWA/IN/JTRP-2004/7, SPR2811. https://doi.org/10.5703/1288284313134

Brierley, G. S., Corkum, D. H., \& Hatem, D. J. (2010). Design-Build Subsurface Projects. SME.

Carnevalli, J. A., \& Miguel, P. C. (2008). Review, analysis and classification of the literature on QFD-Types of research, difficulties and benefits. International Journal of Production Economics, 114(2), 737-754. https://doi.org/10.1016/j.ijpe.2008.03.006

Cheung, S. O., Yiu, T. W., \& Lam, M. C. (2013). Interweaving Trust and Communication with Project Performance. American Society of Civil Engineers, 139(August), 941-951. https://doi.org/10.1061/(ASCE)CO.1943-7862.0000681.

Creedy, G. D., Skitmore, M., \& Wong, J. K. W. (2010). Evaluation of Risk Factors Leading to Cost Overrun in Delivery of Highway Construction Projects. Journal of Construction Engineering and Management, 136(5), 528-537. https://doi.org/10.1061/(asce)co.1943-7862.0000160

Creswell, J. W. (2009). Research design. Qualitative, Quantitative and Mixted Methods Approaches (3rd ed.). Thousand Oaks, California: SAGE Publications Inc.

DBIA. (2014). Transportation Sector. https://doi.org/10.1002/9781118266182.ch4

DeWitt, S., Yakowenko, G., Bohuslav, T., Ferguson, T., Hoelker, E., Molenaar, K. R., ... Wagman, R. (2005). Management Practices in Canada and Europe, 1-72. Retrieved from http://international.fhwa.dot.gov/construction_mgmt/pl05010.pdf

Domenic, V. C. (1994). Guidelines, Criteria, and Rules of Thumb for Evalauting Normed and Standardized Assessment Instruments in Psychology. Psychological Assessment, 6(4), 284-290. https://doi.org/10.1037/1040-3590.6.4.284

Elo, S., \& Kyngäs, H. (2008). The qualitative content analysis process. Journal of Advanced Nursing, 62(1), 107-115. https://doi.org/10.1111/j.13652648.2007.04569.x

Fellows, R. F., \& Liu, A. M. M. (2015). Research Methods for Construction. John Wiley \& Sons. Retrieved from https://ebookcentral.proquest.com/lib/ucb/detail.action?doclD=1895747.

FHWA. (2006). Design-Build Effectiveness.

FHWA. (2017). Alternative Contracting Method Performance in US Highway Construction. McLean, VA.

Fleiss, J. (1972). Measuring nominal scale agreement among many raters. Psychological Bulletin, 76(5), 378-382.

Flyvbjerg, B., Holm, M. S., \& Buhl, S. (2002). Underestimating costs in public works projects: Error or lie? Journal of the American Planning Association, 68(3), 279-295. https://doi.org/10.1080/01944360208976273

FMI. (2018). Design-Build Utilization. Combined Market Study. Retrieved from https://dbia.org/wp-content/uploads/2018/06/Design-Build-MarketResearch-FMI-2018.pdf

Forbes, L. H., \& Ahmed, S. M. (2011). Modern Construction:Lean Project Delivery and Integrated Practices. Boca Raton: Taylor \& Francis.

Harper, C. M., Molenaar, K. R., Anderson, S., \& Schexnayder, C. (2014). Synthesis of Performance Measures for Highway Cost Estimating. Journal of Management in Engineering, 30(3), 04014005. https://doi.org/10.1061/(ASCE)ME.1943-5479 
Hasanzadeh, S., Esmaeili, B., Nasrollahi, S., Gad, G. M., \& Gransberg, D. D. (2018). Impact of Owners' Early Decisions on Project Performance and Dispute Occurrence in Public Highway Projects. Journal of Legal Affairs and Dispute Resolution in Engineering and Construction, $10(2), 04518004$. https://doi.org/10.1061/(asce)la.1943-4170.0000251

Khabisi, J., Aigbavboa, C., \& Thwala, W. (2016). Causes of Cost Overruns in Public Sector Construction Projects in South Africa. In ICCREM (pp. 13111317).

Krippendorff, K. (1980). Content Analysis: An Introduction to its methodology. Thousand Oaks, California: SAGE Publications Inc.

Lam, E. W. M., Chan, Albert P, C., \& Chan, D. W. M. (2006). Barriers to applying the Design-Build procurement method in Hong Kong. Architectural Science Review, 49(2), 189-195. https://doi.org/10.3763/asre.2006.4926

Landis, J. R., \& Koch, G. G. (2013). The Measurement of Observer Agreement for Categorical Data Data for Categorical of Observer Agreement The Measurement. Society, 33(1), 159-174.

Love, P. E. D., Sing, C.-P., Wang, X., Irani, Z., \& Thwala, D. W. (2012). Overruns in transportation infrastructure projects. Structure and Infrastructure Engineering, 10(2), 141-159. https://doi.org/10.1080/15732479.2012.715173

Miller, J. B. (2000). Principles of public and private infrastructure delivery. New York: Springer Science+Business. https://doi.org/10.1007/978-I-4757$6278-5$

Minchin Jr., R. E., Li, X., Issa, R. R., \& Vargas, G. G. (2013). Comparison of Cost and Time Performance of Design-Build and Design-Bid-Build Delivery Systems in Florida. Journal of Construction Engineering and Management, 139(10), 04013007. https://doi.org/10.1061/(ASCE)CO.19437862.0000746

Molenaar, K., Harper, C., \& Yugar-Arias, I. (2014). Guidebook for Selecting Alternative Contracting Methods for Roadway Projects : Project Delivery Methods, Procurement Procedures, and Payment Provisions. Boulder.

Morledge, R., \& Smith, A. (2013). Building Procurement. (J. Wiley, Ed.). ProQuest Ebook Central.

Neuendorf, K. A. (2002). The content analysis Guidebook. Thousand Oaks, California: SAGE Publications Inc

Pakkala, P. (2002). Innovative Project Delivery Methods for Infrastructure - An International Perspective. Helsinki: Finnish Road Enterprise.

Park, J., \& Kwak, Y. H. (2016). Design-Bid-Build (DBB) vs. Design-Build (DB) in the U.S. public transportation projects: The choice and consequences. International Journal of Project Management, 35(3), 280-295. https://doi.org/10.1016/j.ijproman.2016.10.013

PMI. (2014). Study on project schedule and cost overruns. Project Management Institute. India. https://doi.org/10.3920/BM2014.x003

Robson, C. (1993). Real World Research. A resource for Social Scientist and Practitioners-Researches. Oxford: Blackwell Publishers Inc.

Rosenfeld, Y. (2014). Root-Cause Analysis of Construction-Cost Overruns. Journal of Construction Engineering and Management, 140(401), 30-39. https://doi.org/10.1061/(ASCE)CO

Salabeddin M., M. (2012). Cohen's kappa. In Encyclopedia of Research Design (pp. 1-4).

Scott, S., Molenaar, K. R., Gransberg, D. D., \& Smith, N. C. (2006). NCHRP Report 561. Best-Value Procurement Methods for Highway Construction Projects. Washington, D.C.: Transportation Research Board of the National Academies. https://doi.org/10.17226/13982

Shane, J. S., Molenaar, K. R., Anderson, S., \& Schexnayder, C. (2009). Construction Project Cost Escalation Factors. Journal of Management in Engineering, 25(4), 221-229. https://doi.org/10.1061/(ASCE)0742-597X(2009)25:4(221)

Shrestha, P. P., Migliaccio, G. C., O'Connor, J. T., \& Gibson, G. E. (2007). Benchmarking of Large Design-Build Highway Projects: One-to-One Comparison and Comparison with Design-Bid-Build Projects. Transportation Research Record: Journal of the Transportation Research Board, $1994(1), 17-25$. https://doi.org/10.3141/1994-03

Stanford, M. S., Molenaar, K. R., \& Sheeran, K. M. (2016). Application of Indefinite Delivery-Indefinite Quantity Construction Strategies at the Federal Level. Journal of Management in Engineering, 32(5), 04016011. https://doi.org/10.1061/(asce)me.1943-5479.0000437

Sullivan, J., El Asmar, M., Chalhoub, J., \& Obeid, H. (2017). Two Decades of Performance Comparisons for Design-Build, Construction Manager at Risk, and Design-Bid-Build: Quantitative Analysis of the State of Knowledge on Project Cost, Schedule, and Quality Alternative Project Delivery in Construction. Journal of Construction Engineering and Management, 143(6). https://doi.org/10.1061/(ASCE)CO.1943-7862.0001282

Tala González, N. I. (2015). Tesis Magister. Identificación de causas que generar modificación de plazos y costos en contratos de ejecución de obras públicas entre los años 2005 y 2015 (Chile). Pontificia Universidad Católica de Chile.

Touran, A., Gransberg, D. D., Molenaar, K. R., Ghavamifar, K., Mason, D. J., \& Fithian, L. A. (2008). TCRP. Document 41: Evaluation of Project Delivery Methods. Washington, D.C.: Transportation Research Board of the National Academies. Retrieved from http://onlinepubs.trb.org/onlinepubs/tcrp/tcrp_webdoc_41.pdf

Tran, D. Q., Diraviam, G., \& Minchin Jr, R. E. (2018). Performance of Highway Design-Bid-Build and Design-Build Projects by Work Types, 144(2), 1-9. https://doi.org/10.1061/(ASCE)CO.1943-7862.0001437.

Tran, D. Q., Nguyen, L. D., \& Faught, A. (2017). Examination of communication processes in design-build project delivery in building construction. Engineering, Construction and Architectral Management, (1), 113-131. Retrieved from www.emeraldinsight.com

US Federal Government. Code of Federal Regulations. Part 636. DB Contracting (2002)

Verweij, S, \& Meerkerk, V. (2015). Reasons for Contract Changes in Implementing Dutch Transportation Infrastructure Projects: An Empirical Exploration Reasons for Contract Changes in Implementing Dutch Transportation Infrastructure Projects : An Empirical Exploration Reasons for Contract. Transport Policy, 37, 195-202. 
Verweij, Stefan, van Meerkerk, I., \& Korthagen, I. A. (2015). Reasons for contract changes in implementing dutch transportation infrastructure projects: An empirical exploration. Transport Policy, 37, 195-202. https://doi.org/10.1016/j.tranpol.2014.11.004

World Bank. (2014). Source of Time and Cost Over-runs in Roadworks Projects - Pilot Study. Sri Lanka: World Bank Group.

Xia, B., Chan, A., Zuo, J., \& Molenaar, K. (2011). Analysis of Selection Criteria for Design-Builders through the Analysis of Requests for Proposal. Journal of Management in Engineering, 29(1), 19-24. https://doi.org/10.1061/(asce)me.1943-5479.0000119

Xia, B., Skitmore, M., \& Zuo, J. (2011). Evaluation of Design-Builder Qualifications through the Analysis of Requests for Qualifications. Journal of Management in Engineering, 28(3), 348-351. https://doi.org/10.1061/(asce)me.1943-5479.0000095

Yu, W., \& Wang, K.-W. (2012). Best Value or Lowest Bid? A Quantitative Perspective. Journal of Construction Engineering and Management, 138(1), 128-134. https://doi.org/10.1061/(ASCE)CO.1943-7862.0000414 